\title{
Evidence for retrovirus infections in green turtles Chelonia mydas from the Hawaiian islands
}

\author{
Rufina N. Casey ${ }^{1}$, Sandra L. Quackenbush ${ }^{1}$, Thierry M. Work ${ }^{2}$, George H. Balazs ${ }^{3}$, \\ Paul R. Bowser ${ }^{1}$, James W. Casey ${ }^{1, *}$
}

${ }^{1}$ Department of Microbiology and Immunology, College of Veterinary Medicine, Cornell University, Ithaca, New York 14853, USA

${ }^{2}$ U.S. Geological Survey, Biological Resources Division, National Wildlife Health Center, Honolulu Field Station, Honolulu, Hawaii 96850, USA

${ }^{3}$ National Marine Fisheries Service, Southwest Fisheries Science Center, Honolulu Laboratory, Honolulu, Hawaii 96822-2396, USA

\begin{abstract}
Apparently normal Hawaiian green turtles Chelonia mydas and those displaying fibropapillomas were analyzed for infection by retroviruses. Strikingly, all samples were positive for polymerase enhanced reverse transcriptase (PERT) with levels high enough to quantitate by the conventional reverse transcriptase (RT) assay. However, samples of skin, even from asymptomatic turtles, were RT positive, although the levels of enzyme activity in healthy turtles hatched and raised in captivity were much lower than those observed in asymptomatic free-ranging turtles. Turtles with fibropapillomas displayed a broad range of reverse transcriptase activity. Skin and eye fibropapillomas and a heart tumor were further analyzed and shown to have reverse transcriptase activity that banded in a sucrose gradient at $1.17 \mathrm{~g} \mathrm{ml}^{-1}$. The reverse transcriptase activity purified from the heart tumor displayed a temperature optimum of $37^{\circ} \mathrm{C}$ and showed a preference for $\mathrm{Mn}^{2+}$ over $\mathrm{Mg}^{2+}$. Sucrose gradient fractions of this sample displaying elevated reverse transcriptase activity contained primarily retroviralsized particles with prominent envelope spikes, when negatively stained and examined by electron microscopy. Sodium dodecylsulfate-polyacrylamide gel electrophoresis (SDS-PAGE) analysis of gradient-purified virions revealed a conserved profile among 4 independent tumors and showed 7 prominent proteins having molecular weights of $116,83,51,43,40,20$ and $14 \mathrm{kDa}$. The data suggest that retroviral infections are widespread in Hawaiian green turtles and a comprehensive investigation is warranted to address the possibility that these agents cause green turtle fibropapillomatosis (GTFP).
\end{abstract}

KEY WORDS: Green turtle · Reverse transcriptase · Retrovirus · Fibropapillomatosis · Electron microscopy

\section{INTRODUCTION}

Green turtles Chelonia mydas are affected by a proliferative cutaneous lesion referred to as green turtle fibropapillomatosis (GTFP) (Lucke' 1938, Smith \& Coates 1938, Balazs 1991, Aguirre et al. 1994, Herbst 1994, Balazs et al. 1997). Although benign, the tumors are life-threatening since they not only compromise the host physiologically, but also affect its ability to compete in the natural environment (Smith \& Coates 1938, Norton et al. 1990, Balazs 1991, Ehrhart 1991, Harshbarger 1991, Balazs et al. 1997). Like many proliferative diseases of poikilotherms, fibropapillomatosis has been observed to regress in a few cases, but the mecha-

•Addressee for correspondence.E-mail: jwc3@cornell.edu nism responsible has not been delineated (Ehrhart 1991). Additionally, like many tumors of fish, GTFP displays a pattern of prevalence that appears, at least in Florida, to correlate with seasonal changes (Poulet et al. 1994, Herbst \& Jacobson 1995). Fibropapillomas are also known to occur in the loggerhead Caretta caretta and possibly other sea turtles but no etiologic agents have been identified (Harshbarger 1991).

There are numerous indications that GTFP is an infectious disease (Balazs 1991, Herbst 1994). The prevalence of papillomas, fibromas and fibropapillomas on green turtles appears to be increasing worldwide. Outbreaks of GTFP in colonies of captive turtles and the increased prevalence at many different geographic locations are consistent with an infectious etiology (Jacobson et al. 1989, Norton et al. 1990, Herbst et 
al. 1995, 1996). Experimental transmission data showing that GTFP can be induced with a cell-free tumor filtrate as an inoculum supports the hypothesis that a virus is responsible for this disease (Herbst et al. 1995, 1996). Involvement of a herpesvirus has been suspected but it has not been cultured or characterized further (Jacobson et al. 1991). A search for a turtle papilloma-type virus employing nucleic acid methods failed to yield affirmative results (Jacobson et al. 1989).

Although retroviruses have the well-established ability to induce proliferative diseases in birds, mammals, and now fish, relatively little is known about their genetic structure and prevalence in reptiles and invertebrates, or their possible role in tumor induction (Bowser \& Casey 1993, Poulet et al. 1994). This is due, in part, to the absence of cell culture systems for propagation, a deficit that initially hindered the characterization of complex retroviruses from humans and animals (Walker 1969, Van Der Maaten \& Miller 1976, Poiesz et al. 1980, Yamamoto et al. 1985, Popovic et al. 1994, Poulet et al. 1994).

To initially screen green turtles with and without fibropapillomas for the presence of retrovirus, we employed the sensitive PERT assay (Pyra et al. 1994). Three additional experimental approaches were used to provide evidence in support of the contention that retroviral infections are widespread in the Hawaiian green turtles and that GTFP may have a retroviral etiology.

\section{MATERIALS AND METHODS}

Source of tissues. Tissues used in this study originated from 3 groups of green turtles. The first group included tissues from 5 moribund turtles from the islands of Maui and Oahu that were severely afflicted with fibropapillomatosis. These turtles were humanely euthanized and necropsied, and tissues were stored individually in sterile plastic bags at $-70^{\circ} \mathrm{C}$. Additional tissues included biopsies of normal-appearing skin from tumor-free healthy turtles from 2 other groups including free-ranging turtles from the Kona Coast of the island of Hawaii where fibropapillomatosis has not been documented and turtles raised in captivity from hatchlings at Sea Life Park Hawaii, Oahu. Fibropapillomatosis has historically been absent from all green turtles hatched, raised and exibited at this facility. For each turtle, biopsies were procured from the hind flipper using $6 \mathrm{~mm}$ sterile biopsy punches. Biopsies were stored in cryovials at $-70^{\circ} \mathrm{C}$ within 5 min of collection. Ten biopsies were pooled to obtain enough material to assay. Pools 1 and 2 each contained biopsies from 3 turtles. Pools 3 and 4 each contained biopsies from 4 turtles.
Polymerase enhanced reverse transcriptase (PERT) assay. The PERT assay was carried out exactly as described by Pyra et al. (1994). All samples prepared as below ('Virus purification') were assayed at multiple $\log$ dilutions. To verify authenticity, the PCR products were visualized by ethidium bromide staining, and Southern blots were carried out using a ${ }^{32} \mathrm{P}$ kinase labeled internal oligonucleotide probe (Pyra et al. 1994). Hybridization was performed at $37^{\circ} \mathrm{C}$ for $10 \mathrm{~h}$ (Kim \& Casey 1992). Each blot was washed twice for $15 \mathrm{~min}$ in a $2 \times \mathrm{SSC}$ solution ( $\mathrm{SSC}$ is $0.15 \mathrm{M}$ sodium chloride, $0.015 \mathrm{M}$ sodium citrate) containing $0.1 \%$ sodium dodecyl sulfate (SDS) and once in $0.2 \times$ SSC solution also containing $0.1 \%$ SDS. Both washes were at room temperature and the blots air dried and exposed to Kodak XRP film for autoradiography. The positive control employed throughout this study was walleye dermal sarcoma virus (WDSV) that was prepared from tumors as previously described (Martineau et al. 1991a, b).

Reverse transcriptase assay. Reverse transcriptase (RT) assays were performed as previously reported (Martineau et al. 1991b). Aliquots of $10 \mu \mathrm{l}$ from either discontinuous step or continuous sucrose gradients were assayed in a final volume of $50 \mu \mathrm{l}$ containing $50 \mathrm{mM}$ Tris- $\mathrm{HCl} \mathrm{pH} 7.8,20 \mathrm{mM} \mathrm{KCl}, 6 \mathrm{mM} \mathrm{MnCl}_{2}$, $2 \mathrm{mM}$ dithiothreitol, $20 \mathrm{\mu g} \mathrm{ml}^{-1}$ polyribonucleic acid,

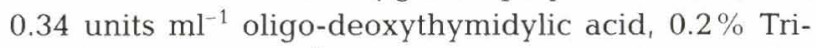
ton $\mathrm{X}-100$, and $2 \mu \mathrm{M}{ }^{3} \mathrm{H}$-thymidine triphosphate, with a specific activity of $82 \mathrm{Ci} \mathrm{mM}^{-1}$ (DuPont NEN). The reaction was incubated for $2 \mathrm{~h}$ at $30^{\circ} \mathrm{C}$ and spotted on filter paper strips (Whatman D-81). The strips were then washed 5 times for $5 \mathrm{~min}$ in $2 \%$ sodium phosphate followed by a $1 \mathrm{~min}$ wash in distilled water and a $1 \mathrm{~min}$ wash in $95 \%$ ethanol. The incorporated radioactivity was measured in a Beckman LS1801 scintillation counter.

Virus purification. Virus purification from tissues was carried out according to previously reported procedures (Mullins et al. 1981, Martineau et al. 1991b, Renshaw et al. 1991). Unless otherwise stated, all operations were performed at $4^{\circ} \mathrm{C}$. In brief, $1 \mathrm{~g}$ of turtle tissue, stored at $-70^{\circ} \mathrm{C}$, was minced and dounce homogenized in 10 volumes $\mathrm{g}^{-1}$ of TNES $(10 \mathrm{mM}$ Tris- $\mathrm{HCl}$ pH 7.5, 1 mM EDTA, $100 \mathrm{mM} \mathrm{NaCl}, 5 \%$ sucrose). The homogenate was centrifuged at $10000 \times g$ for $20 \mathrm{~min}$. The supernatant was centrifuged at $100000 \times g$ for $1.5 \mathrm{~h}$ in a SW 28 rotor (Beckman Industries). The pellet was resuspended in $1 \mathrm{ml}$ of TNES and layered on a discontinuous sucrose gradient of equal volumes of 15, 35 and $50 \%$ TNE sucrose. The gradients were centrifuged for $2 \mathrm{~h}$ at $100000 \times \mathrm{g}$ and the 35 to $50 \%$ interface collected, diluted 10-fold with TNE and pelleted at $100000 \times g$ for $1.5 \mathrm{~h}$. The pellet was resuspended in $100 \mu \mathrm{l}$ of TNES with $6 \mathrm{mM}$ dithiothreitol and stored at 
$-70^{\circ} \mathrm{C}$. Equal aliquots of these preparations from the same amount of starting material were employed in either the PERT or conventional RT assays to allow for Comparison. For gradient analysis, the initial $100000 \times g$ pellet from $10 \mathrm{~g}$ of tumor was resuspended in $1 \mathrm{ml}$ of TNE, layered on a 15 to $60 \%$ continuous sucrose gradient and centrifuged for $16 \mathrm{~h}$ at $100000 \times \mathrm{g}$.

Electron microscopy. The sucrose fractions with peak activities by the RT assay were diluted 10 -fold with TNE and pelleted at $100000 \times g$ for $1.5 \mathrm{~h}$. Each pellet was resuspended in $1 \mathrm{ml}$ of TNE. Formvar grids were floated on $20 \mu \mathrm{l}$ of this suspension for $2 \mathrm{~min}$, then stained for 3 min with phosphotungstic acid.

Protein analysis. Samples from sucrose gradients were adjusted for equivalent amounts of protein, suspended in sample buffer $(62.5 \mathrm{mM}$ Tris-HCl $\mathrm{pH} 6.8$, $10 \%$ glycerol, $2 \%$ SDS, 5\% $\beta$-mercaptoethanol), boiled for $4 \mathrm{~min}$, and resolved by sodium dodecyl sulfate-polyacrylamide gel electrophoresis (SDS-PAGE) (Laemmli 1970). Gels were stained with $0.01 \%$ Coomassie blue, $40 \%$ methanol, and $10 \%$ acetic acid, then destained in $40 \%$ methanol and $10 \%$ acetic acid.

\section{RESULTS}

\section{PERT and RT assays}

We initially employed the PERT assay (Pyra et al. 1994) to screen tumor and non-tumor tissue from tumor-bearing turtles, as well as skin biopsy samples from unaffected turtles, for the presence of reverse transcriptase activity. Five samples from turtles with fibropapillomatosis, including tumors and skin that were not grossly affected, and 4 samples from pools of unaffected turtles demonstrated reverse transcriptase activity detected by the amplification of a predicted 112 bp PCR product (Fig. 1). The PERT assay is sensitive to a reported level of 1 virion per sample and thus is valuable in detecting very low levels of retroviral
Table 1. PERT and reverse transcriptase activities in GTFP associated tumors, uninvolved tissues and tissues pooled from asymptomatic turtles. Reverse transcriptase activity is expressed as counts $\mathrm{min}^{-1}$. The background of 125 counts was subtracted from each sample. FP: fibropapilloma

\begin{tabular}{|c|c|c|c|}
\hline Case no. & Tissue & PERT & RT activity \\
\hline \multicolumn{4}{|c|}{ Turtles with GTFP } \\
\hline $12350-10$ & Eye tumor & + & 301 \\
\hline $12350-2$ & $\mathrm{FP}$ & + & 7235 \\
\hline $12354-33$ & Skin & + & 613 \\
\hline $12354-4$ & FP & + & 6756 \\
\hline $12354-13$ & FP & + & 4043 \\
\hline $12354-17$ & Eye tumor & + & 15138 \\
\hline $12355-17$ & Skin & + & 814 \\
\hline $12355-5$ & FP & + & 1698 \\
\hline $12355-10$ & FP & + & 8210 \\
\hline $12355-06$ & Eye tumor & + & 8184 \\
\hline $12368-1$ & Heart tumor & + & 11320 \\
\hline $12368-11$ & FP & + & 3774 \\
\hline $12368-28$ & FP & + & 5034 \\
\hline $12368-1-35$ & Skin & + & 6321 \\
\hline $12377-1$ & Lung tumor & + & 4086 \\
\hline $12377-1-1$ & Lung tumor & + & 1462 \\
\hline $12377-22$ & $\mathrm{FP}$ & + & 1932 \\
\hline $12377-28$ & Skin & + & 5864 \\
\hline $12377-1$ & Kidney tumor & + & 4707 \\
\hline \multicolumn{4}{|c|}{ Turtles without GTFP (Sea Life Park) } \\
\hline Pool 1 & Skin & + & 597 \\
\hline Pool 2 & Skin & + & 464 \\
\hline \multicolumn{4}{|c|}{ Turtles without GTFP (free-ranging) } \\
\hline Pool 3 & Skin & + & 5110 \\
\hline Pool 4 & Skin & + & 4494 \\
\hline \multicolumn{4}{|c|}{ Positive control } \\
\hline WDSV & WDS & + & 28320 \\
\hline
\end{tabular}

expression. In these experiments the PERT assays were still positive at 3 log dilutions, suggesting relatively high levels of virus in these tissues (Fig. 1).

Conventional RT assays were carried out on all of the above samples to provide a quantitative measure of reverse transcriptase levels. Reverse transcriptase activity was measurable in all samples by the RT assay, consistent with the PERT data (Fig. 1, Table 1).
Fig. 1. Southern blot of PERT amplified products from turtle tissue homogenates. The samples analyzed are: lane 1 , eye tumor 12354-17; lane 2 , eye tumor 12355-06; lane 3, skin 12368-1-35; lane 4, skin 12377-28; lane 5, kidney tumor 12377-1; lane 6, pool 1 of skin biopsis from Sea Life Park; lane 7, pool 2 of skin biopsis from Sea Life Park; lane 8, pool 3 of skin biopsis from free-ranging turtles: lane 9 , pool 4 of skin biopsis from freeranging turtles; lane 10 , negative control, no homogenate added; lane 11 , positive control WDSV

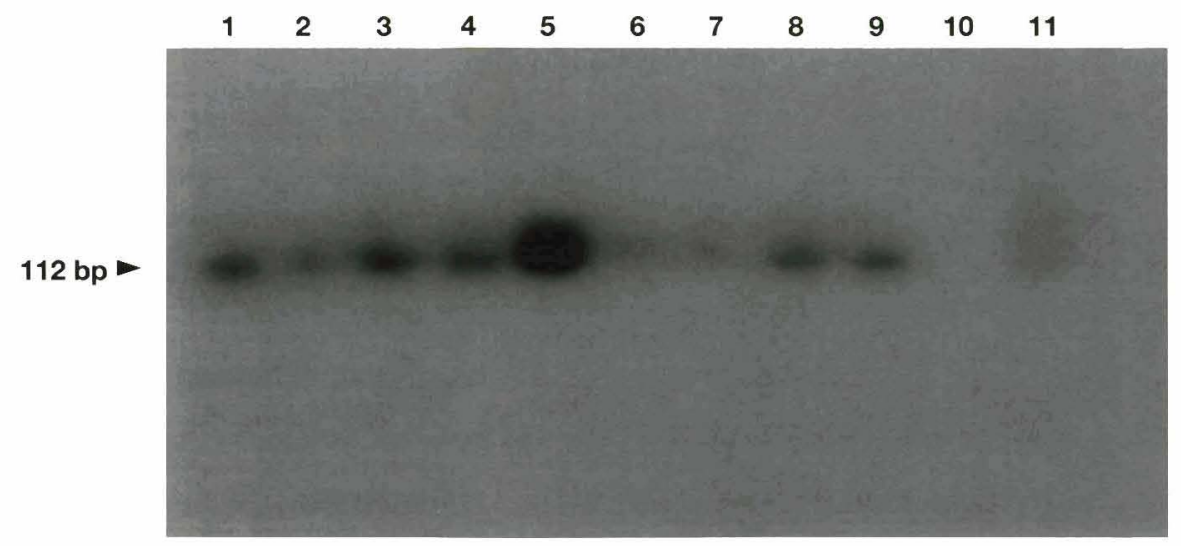




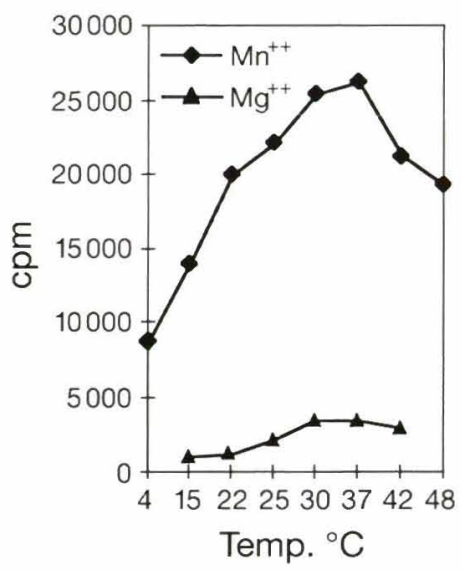

Fig. 2. Temperature dependence of reverse transcriptase activity from heart tumor 12368-1. A $20 \mu \mathrm{l}$ aliquot from a pool of sucrose gradient fractions having high reverse transcriptase activity, Fig. $3 \mathrm{C}$ fractions 3 to 10 , were assayed at the temperatures indicated with either $\mathrm{Mn}^{++}$ or $\mathrm{Mg}^{++}$as the divalent ion

Using the conventional RT assay, the divalent ion $\mathrm{Mn}^{2+}$ gave activities approximately 10 -fold higher than did $\mathrm{Mg}^{2+}$ (Fig. 2). The numbers generated by the RT assay presumably reflect amounts of virus; with the exception of 12350-10 (eye tumor), they spanned an 11-fold range from one tumor to another (Table 1). Maximal activity of the turtle RT was at $37^{\circ} \mathrm{C}$ (Fig. 2). The marine environmental temperature range encountered by green turtles in the Hawaiian Islands is approximately 21 to $29^{\circ} \mathrm{C}$.

\section{Sucrose gradient purification of viral particles and electron microscopy}

Retroviruses characteristically band at a density between 1.15 and $1.18 \mathrm{~g} \mathrm{ml}^{-1}$ in equilibrium density sucrose gradients. Three tumor sample extracts analyzed in this manner, (A) 12354-13 fibropapilloma, (B) 12354-17 eye, and (C) 12368-1 heart, are shown in Fig. 3. The heart tumor and fibropapilloma samples demonstrated high activities by the RT assay, banding at 1.16 and $1.17 \mathrm{~g} \mathrm{ml}^{-1}$ respectively. The eye tumor showed the highest overall activity (Table 1), although very little of it banded at a density characteristic of intact retrovirus, suggesting extensive viral degradation (Fig. 3B).

Aliquots from the sucrose gradient fractions of the heart tumor, 12368-1, corresponding to maximal activity by the RT assay were examined by electron microscopy. Fig. 4 shows 6 particles, all displaying numerous external spikes. Particles with such projec-
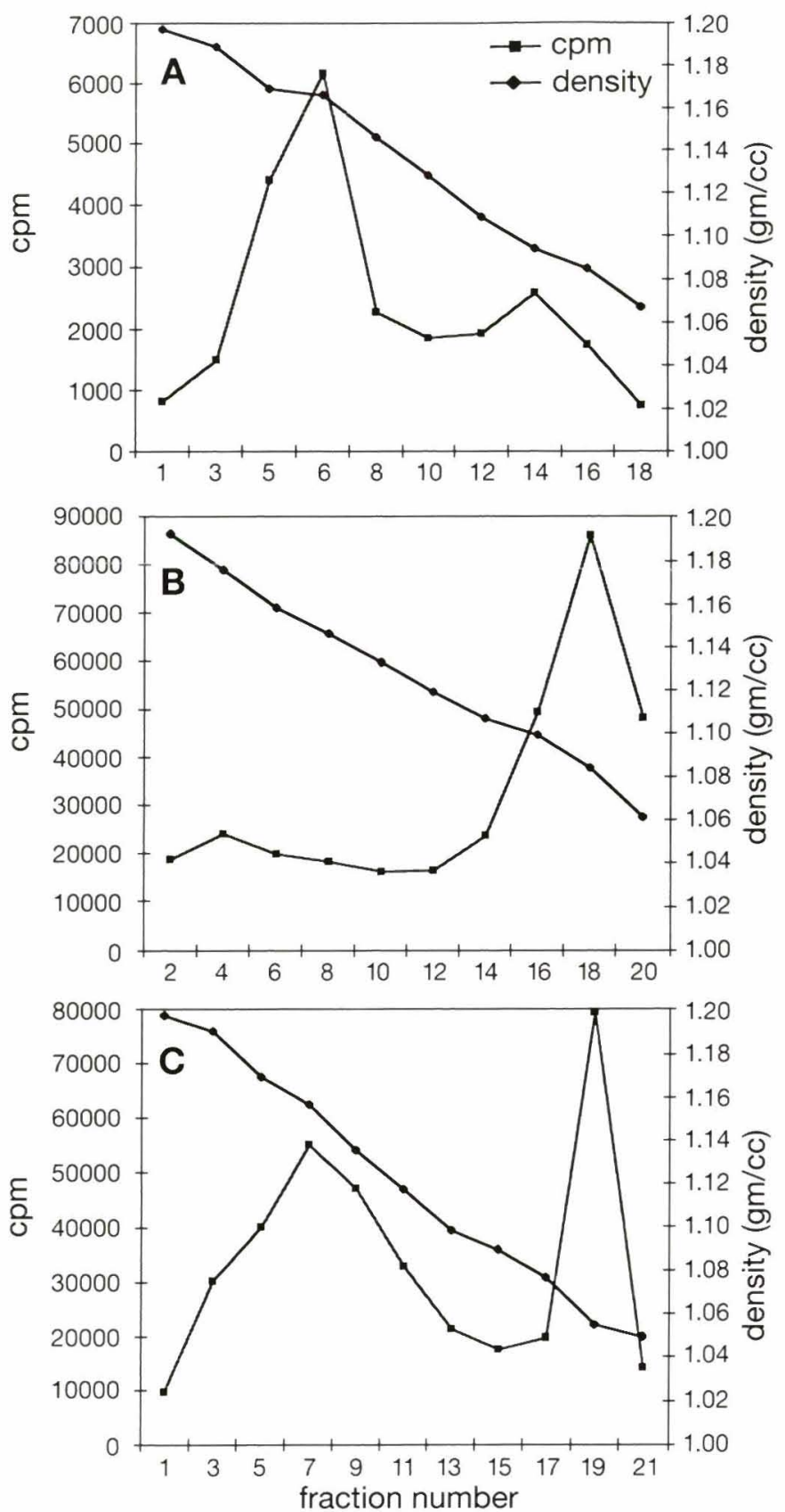

Fig. 3. Sucrose gradient analysis of turtle tumor homogenates. Of each $2 \mathrm{ml}$ fraction, $20 \mu \mathrm{l}$ was assayed for reverse transcriptase activity. (A) Tumor homogenate from fibropapilloma sample 12354-13, (B) tumor homogenate from eye sample 12354-17, and (C) tumor homogenate from heart sample 12368-1. Density was derived from the refractive index

tions, presumably representing envelope glycoproteins, comprised approximately $10 \%$ of all fragments and vesicles in a field. The majority of these particles ranged in size from 96 to $122 \mathrm{~nm}$; one notable exception measured $170 \mathrm{~nm}$ (Fig. 4B). 
Fig. 4. Electron microscopy of particles found in sucrose gradient fractions having high reverse transcriptase activity from heart tumor sample 12368-1. Size measurements were made at the points shown by the $\mathrm{X}$ and calculated from the final magnification: (A) $96 \mathrm{~nm}$, (B) $170 \mathrm{~nm}$, (C) $108 \mathrm{~nm}$, (D) $121 \mathrm{~nm}$, (E) $122 \mathrm{~nm}$, (F) $96 \mathrm{~nm}$
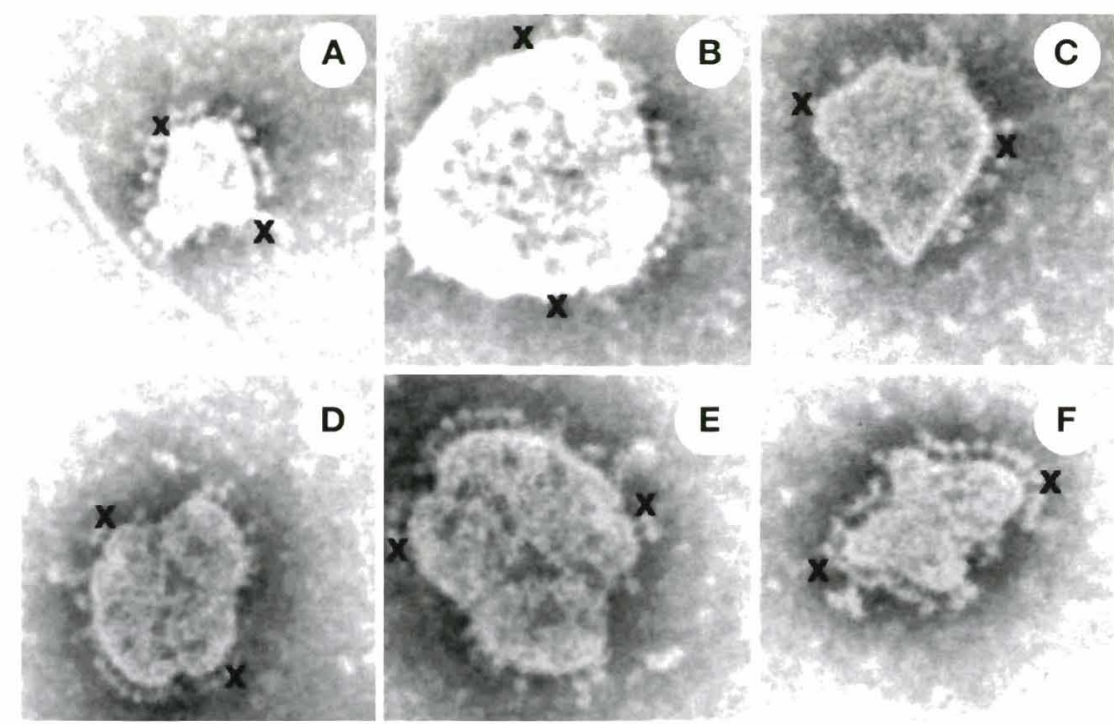

\section{Protein analysis}

An SDS-PAGE analysis was obtained from discontinuous sucrose gradient virus preparations of samples of tumors and uninvolved skin (Fig. 5A). Although a background protein staining was present,

A

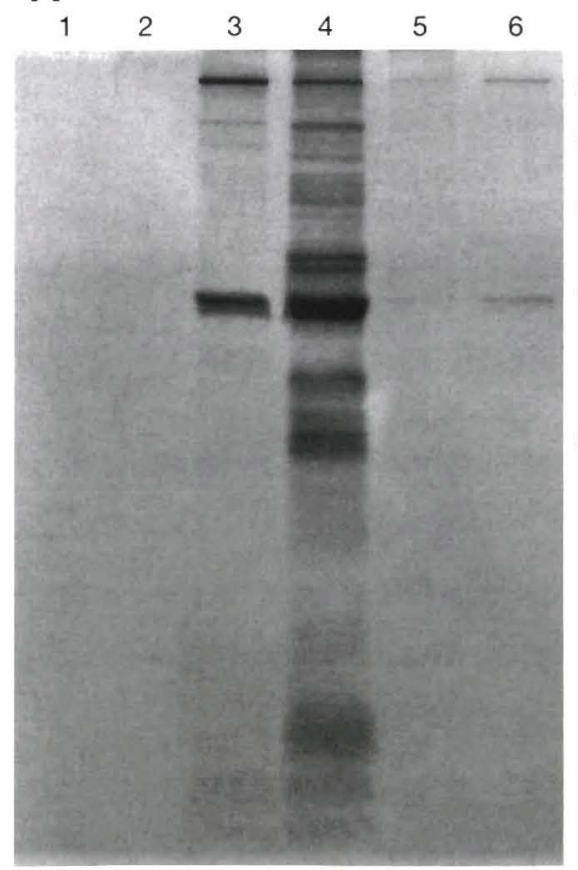

B

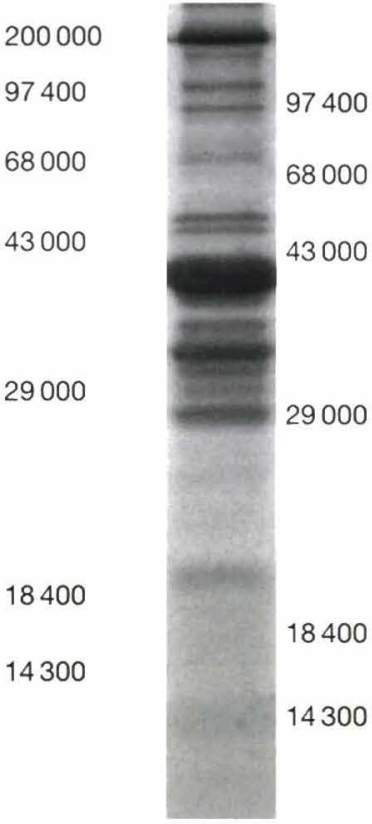

Fig. 5. SDS-PAGE analysis of homogenates from uninvolved skin and tumors. (A) Lane 1, skin 12355-17; lane 2, skin 12354-33; lane 3, lung tumor 12377-1; lane 4, heart tumor 12368-1; lane 5, fibropapilloma 12355-10; lane 6, fibropapilloma 12354-4. (B) Heart tumor sample 12368-1 purified as in Fig. 3 no discrete protein bands were detected from uninvolved skin samples from the 2 tumor positive turtles (Fig. 5A, lanes 1 and 2). The protein banding patterns were similar among the different tumor samples examined although the staining intensity differed. Fractions pooled from a continuous sucrose gradient of the heart sample were assessed by SDS-PAGE analysis (Fig. 5B). Seven prominent polypeptides, with estimated molecular weights of $116,83,51,43,40,20$ and $14 \mathrm{kDa}$, were visualized.

\section{DISCUSSION}

Several independent experimental approaches were used to test the Hawaiian population of green turtles for the presence of retroviruses, with the focus of implicating these agents in the etiology of fibropapillomatosis. The PERT assay was initially employed to measure for reverse transcriptase activity because of its increased sensitivity over traditional methods (Pyra et al. 1994). We have recently employed the PERT technique to identify retroviruses in tumors of fish ( $R$. Casey et al. unpubl.). In this study the PERT results convincingly showed that reverse transcriptase activity was present in all tumors and uninvolved skin samples from the same turtles. Furthermore, pools of skin biopsies collected from Sea Life Park Hawaii, a facility where GTFP has never occurred, revealed a low but reproducible PERT signal (Fig. 1, lanes 6 and 7 ). 
As stated earlier, the PERT assay, which is only semiquantifiable under these conditions, remained positive over a 3-log dilution, suggesting substantial levels of retrovirus. The turtle samples were examined by the less sensitive conventional RT assay in an attempt to obtain quantifiable results and to independently verify the high levels of reverse transcriptase activity suggested by the PERT assay. This approach revealed reverse transcriptase activity in all samples. Furthermore, the activities recorded in samples 12354-17 and 12368-1 (Table 1) were among the highest we have observed in a tumor associated with a retrovirus (Casey et al. unpubl.). From previous work on the piscine retrovirus walleye dermal sarcoma virus (WDSV), which is expressed at high levels in spring tumors, we estimated that there were at least 12 virions per tumor cell (Bowser et al. 1996). Judging from the difference in specific activity of the isotope used in that study and the amount of tumor material analyzed in this work, it appears that approximately half as much activity was present in the turtle heart tumor sample.

Sucrose gradient analysis of the tumor extracts was employed to investigate reverse transcriptase activity banding at a density indicative of retrovirus. The activity of the fibropapilloma sample peaked at a density of $1.17 \mathrm{~g} \mathrm{ml}^{-1}$ (Fig. 3A). In contrast, very little activity from the eye tumor sample was associated with this density fraction, suggestive of extensive virus degradation (Fig. 3C). The heart tumor sample displayed a rather broad banding profile around $1.17 \mathrm{~g} \mathrm{ml}^{-1}$ in comparison with the fibropapilloma (Fig. 3). Taken together it appears that the quality of the presumptive turtle retrovirus varies among different samples. Whether or not such variation is tissue specific, due to stage of disease development or a result of tissue necrosis, remains to be investigated. It is noteworthy that the expression and quality of WDSV and virion RNA varied among fish sampled during the year and at different times of the spawning season (Bowser et al. 1996 and unpubl. obs.).

Electron microscopic visualization of sucrose gradient fractions containing high levels of reverse transcriptase activity revealed numerous virus-like particles, most of which ranged from 96 to $122 \mathrm{~nm}$ in size, with one exception measured at $170 \mathrm{~nm}$. Surface projections corresponding to envelope glycoproteins were apparent on these particles, a morphology similar to the prominent spikes observed on the retrovirus WDSV (Martineau et al. 1991a). The irregular distribution of these surface projections and distorted morphology of the particles is likely due to a combination of artifacts induced by the harsh procedures used in sample preparation and by naturally occurring degradation in the tumor. To further implicate a retrovirus in this disease, electron microscopic visualization of budding virus particles and perhaps propagation in cell culture would be informative.

Additional evidence of a retroviral association with GTFP is provided by the SDS-PAGE analysis of 4 tumor samples and uninvolved skin samples from different turtles (Fig. 5). Qualitatively, the protein banding profile is similar in all 4 tumors but quantitatively different in intensity. This difference in staining intensity approximates the level of reverse transcriptase activity in these tumor samples (Table 1) and thus likely a measure of levels of virus. Analysis of sucrose gradient fractions displaying high reverse transcriptase activity marginally improved the staining profile (Fig. 5B). Most importantly this tumor-specific protein staining pattern differs significantly from the nonspecific background staining observed in the uninvolved skin samples (Fig. 5, lanes 1 and 2). Although the origin of the protein staining bands from these tumors cannot be identified, the limited number of specific bands and the conserved pattern among different tumors suggests that they arise from an infectious agent.

Is GTFP caused by a retrovirus? There are 2 major reasons why this question is not answerable with the current data. The primary concern is that reverse transcriptase assays, whether PERT or conventional, do not distinguish between different retroviruses. The possibility that the green turtle is host to multiple retrovirus infections having different disease potential stems from well-established studies in other species. For example, numerous retrovirus infections have been identified in species such as humans, felines and bovines (for review see Levy 1992-1995). Additionally, walleye fish are infected by at least 2 different retroviruses (Walker 1969, Yamamoto et al. 1985, Martineau et al. 1991a, 1992).

Second, this study represents the first attempt to associate a retrovirus with GTFP and is complicated by the problem of not knowing how the agent is spread, the tissue tropism, mode of expression or the degree of pathogenicity associated with infection. This problem could be partially addressed with transmission studies using captive bred turtles which have very low levels of reverse transcriptase activity. In short, the collective results presented in this paper suggest that retroviral infections are widespread in the Hawaiian green turtles and emphasize the need for additional investigations to clarify the role of these putative agents in the etiology of GTFP.

GTFP, though not recognized in Hawaii prior to 1958 or in the Caribbean until the 1930s, now appears to be occurring worldwide at elevated levels (Herbst 1994). The isolated geographic epizootics suggest that GTFP is a complex and multifactorial disease, possibly involving environmental factors as well as infectious agents. Disease transmission studies provide com- 
pelling evidence that an infectious agent is primarily responsible for GTFP (Herbst et al. 1995, Herbst et al. 1996). Identification of the causative agent is required to provide new insights regarding the mechanism of spread of this disease as well as the molecular basis of tumor induction.

\section{LITERATURE CITED}

Aguirre AA, Balazs GH, Zimmerman B, Spraker TR (1994) Evaluation of Hawaiian green turtles (Chelonia mydas) for potential pathogens associated with fibropapillomas. J Wildl Dis 30(1)8-15

Balazs GH (1991) Current status of fibropapillomas in the Hawaiian green turtle, Chelonia mydas. In: Balazs GH, Pooley SG (eds) Research plan for marine turtle fibropapilloma, US Dept Commer, NOAA Tech Memo NMFSSWFSC-156, p 47-57

Balazs GH, Aguirre AA, Murakawa SKK (1997) Occurrence of oral fibropapillomas in the Hawaiian green turtle. Mar Turtle Newsl 76:1-2

Bowser PR, Casey JW (1993) Retroviruses of fish. Annu Rev Fish Dis 1:209-224

Bowser PR, Wooster GA, Quackenbush SL, Casey RN, Casey JW (1996) Comparison of fall and spring tumors as inocula for experimental transmission of walleye dermal sarcoma. J Aquat Anim Health 8:78-81

Ehrhart LM (1991) Fibropapillomas in green turtles of the Indian River lagoon, Florida: distribution over time and area. In: Balazs GH, Pooley SG (eds) Research plan for marine turtle fibropapilloma. US Dept Commer, NOAA Tech Memo NMFS-SWFSC-156, p 113

Harshbarger JC (1991) Sea turtle fibropapilloma cases in the registry of tumors in lower animals. In: Balazs GH, Pooley SG (eds) Research plan for marine turtle fibropapilloma. US Dept Commer, NOAA Tech Memo NMFS-SWFSC156, p 63-70

Herbst LH (1994) Fibropapillomatosis of marine turtles. Annu Rev Fish Dis 4:389-425

Herbst LH, Jacobson ER (1995) Diseases of marine turtles. In: Bjorndal KA (ed) Biology and conservation of sea turtles, 2nd edn. Smithsonian Institution Press, Washington, DC, p $593-596$

Herbst LH, Jacobson ER, Moretti R, Brown T, Sundberg JP, Klein PA (1995) Experimental transmission of green turtle fibropapillomatosis using cell-free tumor extracts. Dis Aquat Org 22:1-12

Herbst LH, Moretti R, Brown T, Klein PA (1996) Sensitivity of the transmissable green turtle fibropapillomatosis agent to chloroform and ultracentrifugation conditions. Dis Aquat Org 25:225-228

Jacobson ER, Buergelt C, Williams B, Harris RK (1991) Herpesvirus in cutaneous fibropapillomas of the green turtle, Chelonia mydas. Dis Aquat Org 12:1-6

Jacobson ER, Mansell JL, Sundberg JP, Hajjar L, Reichmann ME, Ehrhart LM, Walsh M, Murru F (1989) Cutaneous fibropapillomas of green turtles (Chelonia mydas). J Comp Pathol 101:39-52

Editorial responsibility: Peernel Zwart,

Utrecht, The Netherlands
Kim CH, Casey JW (1992) Genomic variation and segregation of equine infectious anemia virus during acute infection. J Virol 66:3879-3882

Laemmli UK (1970) Cleavage of structural proteins durning the assembly of the head of bacteriophage T4. Nature 227: $680-685$

Levy JA (1992-95) The Retroviridae, Vol 1-4. New York Plenum Press

Lucke' B (1938) Studies on tumors in cold-blooded vertebrates. Annu Rep Tortugas Laboratory Carnegie Institute, Washington, DC, 1937-38:92-94

Martineau D, Bowser PR, Renshaw RR, Casey JW (1992) Molecular characterization of a unique retrovirus asociated with a fish tumor. J Virol 66(1):596-599

Martineau D, Renshaw R, Bowser PR, Casey JW (1991a) Initial characterization of a retrovirus found in walleyes (Stizostedion vitreum). 2nd Int Symp Virus Lower Vertebrates $157-163$

Martineau D, Renshaw R, Williams JR, Casey JW, Bowser PR (1991b) A large unintegrated retrovirus DNA species present in a dermal tumor of walleye Stizostedion vitreum. Dis Aquat Org 10:153-158

Mullins J, Casey J, Nicholson M, Davidson N (1981) Molecular cloning of feline leukemia integrated proviral DNA in Charon 4A: analysis of infectious and non-infectious clones. J Virol 38:688-703

Norton TM, Jacobson ER, Sundberg JP (1990) Cutaneous fibropapillomas and renal myxofibroma in a green turtle, Chelonia mydas. J Wildl Dis 26:265-270

Poiesz BJ, Ruscetti FW, Gazdar AF, Bunn PA, Minna JD, Gallo RC (1980) Detection and isolation of type C retrovirus particles from fresh and cultured lymphocytes of a patient with cutaneous T-cell lymphoma. Proc Natl Acad Sci USA 77:7415-7419

Popovic M, Sarngadharan MG, Read E, Gallo RC (1994) Detection, isolation, and continuous production of cytopathic retroviruses from patients with AIDS and pre-AIDS. Science 224:497-500

Poulet FM, Bowser PR, Casey JW (1994) Retroviruses of fish, reptiles, and molluscs. In: Levy JA (ed) The Retroviridae, Vol 3. Plenum Press, New York, p 1-38

Pyra H, Boni J, Schupbach J (1994) Ultrasensitive retrovirus detection by a reverse transcriptase assay based on product enhancement. Proc Natl Acad Sci USA 91:15544-15548

Renshaw RW, Gonda MA, Casey JW (1991) Viral DNA structure and transcriptional status of bovine syncytial virus in cytopathic infections. Gene 105:179-184

Smith GM, Coates CW (1938) Fibro-epithelial growths of the skin in large marine turtles Chelonia mydas (L.). Zoologica, NY 23:93-98

van der Maaten MJ, Miller J (1976) Replication of bovine leukemia virus in monolayer cell culture. Bibl Haematol (43):360-362

Walker R (1969) Virus associated with epidermal hyperplasia in fish. Natl Canc Inst Monogr 31:195-207

Yamamoto T, Kelly RK, Nielson O (1985) Epidermal hyperplasia of walleye, Stizostedion vitreum vitreum (Mitchill), associated with retrovirus-like type-C particles: prevalence, histologic and electron microscopic observations. J Fish Dis 8:425-436

Submitted: February 20, 1997; Accepted: July 18, 1997

Proofs received from author(s): October 13, 1997 